\section{Media Selection and Seed Coating Influence Germination of Turfgrasses under Salinity}

\author{
Matteo Serena \\ Department of Plant and Environmental Sciences, New Mexico State \\ University, MSC 3Q, Las Cruces, NM 88003
}

\author{
Bernd Leinauer ${ }^{1}$ \\ Department of Extension Plant Sciences, New Mexico State University, MSC \\ 3AE, P.O. Box 30003, Las Cruces, NM 88003
}

\author{
Rossana Sallenave \\ Extension Animal Sciences and Natural Resources Department, New Mexico \\ State University, MSC 3AE, Las Cruces, NM 88003
}

\section{Marco Schiavon \\ Department of Plant and Environmental Sciences, New Mexico State University, MSC 3Q, Las Cruces, NM 88003}

\section{Bernd Maier}

Department of Extension Plant Sciences, New Mexico State University, MSC $3 A E$, Las Cruces, NM 88003

Additional index words. Agar, filter paper, ZEBA ${ }^{\circledR}$

\begin{abstract}
Germination of five turfgrass species ['Barrister' kentucky bluegrass (Poa pratensis L.), 'Barvado' tall fescue (Festuca arundinacea Schreb.), 'Premier II' perennial ryegrass (Lolium perenne L.), 'Bargusto' bermudagrass (Cynodon dactylon L. Pers.), and 'Sea Spray' seashore paspalum (Paspalum vaginatum O. Swartz)] from coated (ZEBA ${ }^{\circledR}$ cornstarch coating; Absorbent Technologies Inc., Beaverton, OR) and uncoated seeds was evaluated on both filter paper and agar. Final germination percentage (FGP) and germination rate (GR) were determined at salinity levels of 0.6 (tap water, control), 2.2 (saline groundwater from a local shallow aquifer), and 7.0, 12.5, and $22.5 \mathrm{dS} \cdot \mathrm{m}^{-1}$ [sodium chloride and calcium chloride (1:1, w:w) dissolved in tap water]. Final germination percentage for kentucky bluegrass, perennial ryegrass, and tall fescue was greater in agar at all salinity levels but was unaffected by the medium at any of the salinities except for $7 \mathrm{dS} \cdot \mathrm{m}^{-1}$ for bermudagrass and seashore paspalum. Coated seashore paspalum and coated perennial ryegrass seed exhibited greater germination than uncoated seed at four of the five salinity levels. Seed coating had no effect on FGP of bermudagrass at any salinity level and coated kentucky bluegrass seed showed reduced germination at 0.6 and $7.0 \mathrm{dS} \cdot \mathrm{m}^{-1}$. Final germination percentage for seashore paspalum improved from $22 \%$ to $54 \%$ at $12.5 \mathrm{dS} \cdot \mathrm{m}^{-1}$ and from $8 \%$ to $20 \%$ at $22.5 \mathrm{dS} \cdot \mathrm{m}^{-1}$ when coated seed was used instead of uncoated seed. Germination rates were unaffected by salinity levels ranging from 0.6 to $12.5 \mathrm{dS} \cdot \mathrm{m}^{-1}$ and were higher on agar $(10 \% /$ day $)$ than on paper $(8 \% / \mathrm{day})$. Our study suggests that the choice of medium can influence the outcome of germination tests and that results can also vary depending on the salinity level tested and whether the seed are coated.
\end{abstract}

\footnotetext{
Received for publication 8 Sept. 2011. Accepted for publication 19 Nov. 2011

Financial support of the study was provided by New Mexico State University's Agricultural Experiment Station, by the Cooperative State Research, Education, and Extension Service, U.S. Department of Agriculture under Agreement No. 2005-34461-15661 and 2005-45049-03209, and by Barenbrug USA.

We are grateful for the donations from Scotts Co. and for the help and support of M. Gill at New Mexico Department of Agriculture's Seed Testing Lab.

${ }^{1}$ To whom reprint requests should be addressed; e-mailleinauer@nmsu.edu.
}

Loss of productive lands as a result of soil salinization is a growing worldwide problem that affects arid zone regions most acutely. This, coupled with a growing scarcity of fresh water and increased use of effluent or lowquality water for turfgrass irrigation, has prompted turfgrass researchers to develop and test salt-tolerant turfgrass varieties. Establishing turfgrass from seeds under saline conditions is becoming increasingly important, particularly in arid regions of the world. The first step in the process of screening for salinity tolerance in any plant species is to conduct a germination test. According to protocols outlined by the Association of Official Seed
Analysts (AOSA, 2009), media considered acceptable for use in standard germination tests include blotter paper, creped cellulose paper, filter paper, sponge rock, vermiculite, sand, and paper toweling. However, it is not clear whether all of these substrata are adequate for screening purposes when the germination test is conducted under saline conditions or when coated seeds are used.

A wide variety of substrata have been used to investigate the effect of salinity on germination of turfgrasses. Dewey (1962) used salinized soil to test wheatgrass (Agropyron desertorum Fisch.) germination at 6,000, 12,000 and $18,000 \mathrm{ppm} \mathrm{NaCl}$ and $\mathrm{CaCl}_{2}$. Harivandi et al. (1982) studied germination of several cool-season grasses on washed sand and germination pads (blotter paper). The sand substrata can be easily used; however, it has little water-holding capacity, which may cause salts to concentrate over the course of the experiments (Dudeck et al., 1986). Others have used hydroponic culture systems to study the effect of salinity on germination and growth of a number of coolseason grasses (Brilman and Sardar, 2010; Horst and Beadle, 1984; Horst and Dunning, 1989; Horst and Taylor, 1983; Richardson and McCalla, 2008; Wu, 1981; Zhang et al., 2011). Although these studies reported differences in salt tolerance among the turfgrasses tested, the saline aqueous environment in which the seeds were exposed may not accurately simulate saline conditions occurring in soil. Moreover, hydroponic culture experiments are very labor-intensive (Dudeck et al., 1986). Agar gel was first used as a germination medium by Torello and Symington (1984) to test the effect of salinity $(10,000 \mathrm{ppm})$ on germination of several kentucky bluegrass, alkaligrass [Puccinella distans (L.) Parl.], and red fescue varieties. Since then, other researchers have used agar to study the effects of various salinity levels on germination of a number of warm- and cool-season grasses (Dai et al., 2009; Dudeck and Peacock, 1985; McCarty and Dudeck, 1993; Peacock and Dudeck, 1989; Wang and Zhang, 2010; Zhang et al., 2011). However, with the exception of Wang and Zhang (2010) and Zhang et al. (2011), only low salinity levels were tested in the aforementioned studies. Blotter or filter paper has also been widely used as a germination medium to screen for salinity tolerance in turfgrasses (Camberato and Martin, 2004; Johnson et al., 2007; Lunt et al., 1961; Marcar, 1987; Qian and Suplick, 2001; Serena et al., 2010; Shahba et al., 2008; Zhang et al., 2011). As reported by Dudeck et al. (1986), blotter paper tends to lose more water than agar media and salinity levels surrounding the seed may be higher in blotter paper than in agar.

Seed coatings were first introduced in the late 1930s and early 1940s (Kaufman, 1991; Ross and Moore, 1975) to improve seeding and establishment of vegetables. More recently coatings have been used to improve the microenvironment of turfgrass seeds (Scott, 1989). Grass seeds have been coated with a number of materials, including limestone (Hathcock 
et al., 1984a), fertilizers (Bruneau et al., 1989; Hathcock et al., 1984b), diatomaceous earth and cytokinins (Greipson, 1999), fungicides (Hummel, 1991; Newell, 1997; Newell et al., 1999), and water adsorbents (Berdhal and Barker, 1980), resulting in increased germination and/or establishment of turf. Since its introduction in 2006, the corn starch coating by the name of $\mathrm{ZEBA}^{\circledR}$ has been promoted for use on warm- and cool-season turfgrass seeds (Ardens, 2007) for its water retention capabilities. The coating consists of a polymer [starch-g-poly (2-propenamide-co-propenoic acid) potassium salt], which, according to the manufacturer, absorbs water up to 400 times its weight (Absorbent Technologies, 2006; Ardens, 2007). Leinauer et al. (2010) documented that ZEBA ${ }^{\circledR}$ coating resulted in increased field emergence of 'Bengal' creeping bentgrass and in improved establishment of several cool-season blends and mixes. The authors also showed that increased moisture retention from seed coating could compensate for reduced seeding rates, reduced irrigation during establishment, and for a combination of both. However, it is not known if seed coating will have similar beneficial effects on germination under saline conditions.

To identify the optimal germination medium for salt tolerance screening of turfgrasses, more studies are needed that compare media, species, and seed treatments. Dudeck et al. (1986) compared germination of perennial ryegrass (Lolium perenne L.) on blotter paper vs. agar at salinity levels of up to $5000 \mathrm{ppm}$. Although the authors found no differences between the two media, only one species was tested, and moderate salinity levels were used. Zhang et al. (2011) compared germination of several varieties of four cool-season species using a maximum salt concentration of $20 \mathrm{~g} \cdot \mathrm{L}^{-1} \mathrm{NaCl}$ and three different media. To date, no studies have compared germination of both warm- and cool-season grasses under highly saline conditions on more than one medium. In addition, studies are lacking on how seed coatings purported to increase moisture retention influence germination under a wide range of salinities. In this study, we compared germination of coated and uncoated cool- and warm-season grasses on two of the most widely used media under low [potable or electrical conductivity $(\mathrm{EC})=0.6$ $\left.\mathrm{dS} \cdot \mathrm{m}^{-1}\right]$ to highly saline conditions $(\mathrm{EC}=$ $\left.22.5 \mathrm{dS} \cdot \mathrm{m}^{-1}\right)$. The substrata chosen for the study were $1 \%$ agar gel and filter paper, and ZEBA $^{\circledR}$ cornstarch material was used on the coated seeds. The objective of this study was to compare the performance of two commonly used media for germinating coated and uncoated turfgrass seed under saline conditions.

\section{Materials and Methods}

The study was conducted from Apr. 2011 to July 2011 at the New Mexico Department of Agriculture's seed testing laboratory. The two germination substrates compared in the study were filter paper and agar. Three coolseason grasses, namely kentucky bluegrass 'Barrister', tall fescue (F. arundinacea Schreb.)
'Barvado', and perennial ryegrass (Lolium perenne L.) 'Premier II', and two warm-season grasses, bermudagrass (Cynodon dactylon L. Pers.) 'Bargusto' and seashore paspalum (Paspalum vaginatum $\mathrm{O}$. Swartz) 'Sea Spray', were included in the study. Uncoated and ZEBA ${ }^{\circledR}$ coated seeds were provided for each species by the seed manufacturer.

The first germination experiment was conducted following the protocol for seed germination on filter paper outlined by the Association of Official Seed Analysts (AOSA, 2009). The five salinity levels tested were: $0.6 \mathrm{dS} \cdot \mathrm{m}^{-1}$ (tap water, control), $2.2 \mathrm{dS} \cdot \mathrm{m}^{-1}$ (saline groundwater from a local shallow aquifer), and three additional saline solutions $\left(7,12.5\right.$, and $\left.22.5 \mathrm{dS} \cdot \mathrm{m}^{-1}\right)$, which were prepared using tap water and sodium chloride $(\mathrm{NaCl})$ and calcium chloride $\left(\mathrm{CaCl}_{2}\right)$ in a ratio by weight of 1:1 (Table 1). One hundred seeds were placed on each filter paper, which had been previously saturated with the desired saline water treatment. The filter papers were then transferred to a plastic $10 \times 10-\mathrm{cm}$ container (Hoffman Manufacturing Inc., Jefferson, OR), covered with a transparent lid, and the container was placed in the germination chamber.

The second germination experiment was conducted using a $1 \%$ Difco Bacto agar substrate (Dudeck and Peacock, 1985). Salinity of the agar medium was adjusted to the aforementioned salinity levels. The agar solution was autoclaved at $120{ }^{\circ} \mathrm{C}$ for $30 \mathrm{~min}$ before use. The agar was poured into $10 \times 1.5-\mathrm{cm}$ Fisherbrand ${ }^{\circledR}$ petri dishes to which 36 seeds were transferred (Dai et al., 2009). Coated and uncoated unsterilized seed from the same seed lots were used in both germination experiments. Petri dishes and plastic boxes were incubated in two different germinators (Stults Scientific Engineering Corp., Springfield, IL), one for warm-season grasses and a second for cool-season grasses. The incubators were programmed to maintain alternating $8 \mathrm{~h}$ light at $25{ }^{\circ} \mathrm{C}$ with fluorescent light $\left(36 \mu \mathrm{mol} \cdot \mathrm{s}^{-1} \cdot \mathrm{m}^{-2}\right)$ and $16 \mathrm{~h}$ dark at $15^{\circ} \mathrm{C}$ for cool-season grasses and $8 \mathrm{~h}$ light at $35{ }^{\circ} \mathrm{C}$ with fluorescent light $\left(36 \mu \mathrm{mol} \cdot \mathrm{s}^{-1} \cdot \mathrm{m}^{-2}\right)$ and $16 \mathrm{~h}$ dark at $20{ }^{\circ} \mathrm{C}$ for warm-season grasses (AOSA, 2009). Experiments were conducted using a completely randomized design with four replications for each treatment combination. The positions of the petri dishes and plastic boxes were rotated inside the germinator three times per week to minimize shelf effects on the study. After germinated seeds were counted, water from the corresponding salinity treatment was added to any filter paper that had dried out. Whether blotter paper required rewetting was determined by pressing a finger firmly into the filter paper.
The moisture level in the filter paper was deemed sufficient if a film of water formed almost around the finger (AOSA, 2009). However, if the filter paper was dry and rewetting was necessary, only enough water was added to supply the needed moisture to the seeds but not enough to create puddling on the filter paper or the formation of film around the seeds (AOSA, 2009). Germination data were collected three times per week for 4 weeks. A seed was considered germinated when the root and shoot could be observed with the naked eye (AOSA, 2009; Qian and Suplick, $2001)$. Germination rate $(\% / d)$ was based on seedling counts taken three times per week (Maguire, 1962), and FGP (\%) was based on the total number of germinated seeds counted after $28 \mathrm{~d}$. Although FGP provides the total germination after the evaluation period of 4 weeks, GR describes the rate of germination with higher values indicating faster rates. All values were subjected to analysis of variance (ANOVA) using SAS Proc Mixed (Version 9.2; SAS Institute Inc., Cary, NC) followed by multiple comparisons of means using Fisher's protected least significant difference test at the $0.05 P$ level.

\section{Results and Discussion}

The ANOVA revealed that the three-way interactions among grass, germination media, and salinity and among grass, coating, and salinity had a significant effect on FGP (Table 2). The ANOVA further revealed that only the single effects of grass, salinity, and media affected GR. To address the significant three-way interactions, FGP was subsequently pooled over seed coating and is displayed separately for each grass and germination media (Table 3). Data were also pooled over germination media and are shown separately for each grass and seed coating (Table 3 ).

Final germination percentage. When data were pooled over seed coating and displayed separately for each grass species and germination media, differences in FGP between seeds germinated on filter paper and agar were observed in 17 of 25 treatment combinations (five grasses $\times$ five salinity levels). In all 17 combinations, germination was higher in agar than on filter paper (Table 3). Germination was greater in agar at all salinity levels for kentucky bluegrass, perennial ryegrass, and tall fescue. Germination of bermudagrass and seashore paspalum was unaffected by the type of medium at any of the salinities except for $7 \mathrm{dS} \cdot \mathrm{m}^{-1}$. Our findings of generally higher germination in agar than on filter paper are in part supported by Zhang et al. (2011) who also reported higher germination

Table 1. Main chemical constituents of saline waters used in germination tests.

\begin{tabular}{|c|c|c|c|c|c|}
\hline & \multicolumn{5}{|c|}{ Electrical conductivity $\left(\mathrm{dS} \cdot \mathrm{m}^{-1}\right)$} \\
\hline Main constituents & 0.6 & 2.2 & 7.0 & 12.5 & 22.5 \\
\hline $\mathrm{pH}$ & 7.6 & 7.7 & 7.8 & 7.5 & 7.6 \\
\hline Bicarbonate $\left(\mathrm{mEq} \cdot \mathrm{L}^{-1}\right)$ & 2.7 & 2.9 & 2.1 & 2.2 & 2.2 \\
\hline Calcium $\left(\mathrm{mEq} \cdot \mathrm{L}^{-1}\right)$ & 2.8 & 7.4 & 35.4 & 59.1 & 105.6 \\
\hline Sodium $\left(\mathrm{mEq} \cdot \mathrm{L}^{-1}\right)$ & 2.5 & 12.5 & 37.6 & 65.3 & 117.5 \\
\hline SAR & 1.9 & 5.6 & 9.0 & 11.7 & 15.5 \\
\hline
\end{tabular}


Table 2. Results of analysis of variance testing the effects of grasses, seed coating, germination media, salinity, and their interactions on final germination and germination rate.

\begin{tabular}{lcc}
\hline & Final germination & Germination rate \\
\hline Coating & $* * *$ & NS \\
Grass & $* * * * *$ \\
Coating*grass & $* * *$ & NS \\
Media & $* * *$ & $* * *$ \\
Coating*media & NS & NS \\
Grass*media & $* * *$ & NS \\
Coating*grass*media & $* * *$ & NS \\
Salinity & $* * *$ & $*$ \\
Coating*salinity & $* *$ & NS \\
Grass*salinity & $* * *$ & NS \\
Coating*grass*salinity & $* * *$ & NS \\
Media*salinity & $* * *$ & NS \\
Coating*media*salinity & NS & NS \\
Grass*media*salinity & $* * *$ & NS \\
Coating*grass*media*salinity & $\mathrm{NS}$ & NS \\
\hline
\end{tabular}

* Significant $\mathrm{F}$ test at the 0.05 level of probability.

**Significant $\mathrm{F}$ test at the 0.01 level of probability.

***Significant $\mathrm{F}$ test at the 0.001 level of probability.

NS $=$ Nonsignificant at the $0.05 P$ level

Table 3. Final germination (\%) of coated and uncoated bermudagrass, kentucky bluegrass, perennial ryegrass, seashore paspalum, and tall fescue seed in two media (agar and filter paper) at salinities of $0.6,2.2,7.0,12.5$, and $22.5 \mathrm{dS} \cdot \mathrm{m}^{-1}$.

\begin{tabular}{|c|c|c|c|c|}
\hline \multirow[b]{2}{*}{ Salinity $\left(\mathrm{dS} \cdot \mathrm{m}^{-1}\right)$} & \multicolumn{2}{|c|}{ Germination media } & \multicolumn{2}{|c|}{ Seed coating } \\
\hline & Agar & Paper & Coated & Uncoated \\
\hline & \multicolumn{4}{|c|}{ Bermudagrass } \\
\hline 0.6 & $94 \mathrm{a}^{\mathrm{z}}$ & $90 \mathrm{a}$ & $91 \mathrm{ab}$ & $93 \mathrm{a}$ \\
\hline 2.2 & $94 \mathrm{a}$ & 89 a & 92 a & $91 \mathrm{ab}$ \\
\hline 7.0 & $89 \mathrm{abA}^{\mathrm{y}}$ & $80 \mathrm{bB}$ & $85 \mathrm{bc}$ & $84 \mathrm{~b}$ \\
\hline 12.5 & $83 \mathrm{~b}$ & $84 \mathrm{ab}$ & $82 \mathrm{c}$ & $86 \mathrm{~b}$ \\
\hline \multirow[t]{2}{*}{22.5} & $73 \mathrm{c}$ & $69 \mathrm{c}$ & $70 \mathrm{~d}$ & $72 \mathrm{c}$ \\
\hline & \multicolumn{4}{|c|}{ Kentucky bluegrass } \\
\hline 0.6 & $93 \mathrm{aA}$ & $82 \mathrm{abB}$ & $83 \mathrm{aB}$ & $92 \mathrm{aA}$ \\
\hline 2.2 & $91 \mathrm{aA}$ & $84 \mathrm{aB}$ & $87 \mathrm{a}$ & $89 a$ \\
\hline 7.0 & $92 \mathrm{aA}$ & $83 \mathrm{aB}$ & $84 \mathrm{aB}$ & $91 \mathrm{aA}$ \\
\hline 12.5 & 89 abA & $77 \mathrm{bB}$ & $84 \mathrm{a}$ & $83 \mathrm{~b}$ \\
\hline \multirow[t]{2}{*}{22.5} & 86 bA & $44 \mathrm{cB}$ & $67 \mathrm{~b}$ & $63 \mathrm{c}$ \\
\hline & \multicolumn{4}{|c|}{ Perennial ryegrass } \\
\hline 0.6 & $96 \mathrm{~A}$ & $89 \mathrm{aB}$ & $95 \mathrm{~A}$ & $90 \mathrm{~B}$ \\
\hline 2.2 & $96 \mathrm{~A}$ & $91 \mathrm{aB}$ & $96 \mathrm{~A}$ & $91 \mathrm{~B}$ \\
\hline 7.0 & $96 \mathrm{~A}$ & $90 \mathrm{aB}$ & 94 & 91 \\
\hline 12.5 & $96 \mathrm{~A}$ & $89 \mathrm{aB}$ & $96 \mathrm{~A}$ & $90 \mathrm{~B}$ \\
\hline \multirow[t]{2}{*}{22.5} & $96 \mathrm{~A}$ & $84 \mathrm{bB}$ & $93 \mathrm{~A}$ & $87 \mathrm{~B}$ \\
\hline & \multicolumn{4}{|c|}{ Seashore paspalum } \\
\hline 0.6 & $64 \mathrm{a}$ & $61 \mathrm{a}$ & 69 aA & $55 \mathrm{aB}$ \\
\hline 2.2 & $59 \mathrm{a}$ & $61 \mathrm{a}$ & $66 \mathrm{abA}$ & $54 \mathrm{aB}$ \\
\hline 7.0 & $60 \mathrm{aA}$ & $50 \mathrm{bB}$ & $59 \mathrm{bc}$ & $52 \mathrm{a}$ \\
\hline 12.5 & $46 \mathrm{~b}$ & $50 \mathrm{~b}$ & $54 \mathrm{cA}$ & $22 \mathrm{bB}$ \\
\hline \multirow[t]{2}{*}{22.5} & $14 \mathrm{c}$ & $14 \mathrm{c}$ & $20 \mathrm{dA}$ & $8 \mathrm{cB}$ \\
\hline & \multicolumn{4}{|c|}{ Tall fescue } \\
\hline 0.6 & $88 \mathrm{~A}$ & $82 \mathrm{~B}$ & $88 \mathrm{~A}$ & $83 \mathrm{abB}$ \\
\hline 2.2 & $88 \mathrm{~A}$ & $81 \mathrm{~B}$ & 84 & $85 \mathrm{a}$ \\
\hline 7.0 & $88 \mathrm{~A}$ & $84 \mathrm{~B}$ & 86 & $86 \mathrm{a}$ \\
\hline 12.5 & $88 \mathrm{~A}$ & $80 \mathrm{~B}$ & $86 \mathrm{~A}$ & $81 \mathrm{bB}$ \\
\hline 22.5 & $88 \mathrm{~A}$ & $81 \mathrm{~B}$ & 86 & $84 \mathrm{ab}$ \\
\hline
\end{tabular}

${ }^{\mathrm{z}}$ Values followed by the same letter are not significantly different from one another (Fisher's protected least significant difference, $\alpha=0.05$ ). Lower case letters denote differences between salinity levels separately for each grass (in columns).

${ }^{y}$ Upper case letters denote differences of the mean values between germination media (agar and paper) and between coated and uncoated seed (in rows).

in 'Declaration' creeping bentgrass and 'Marco Polo' sheep fescue at several salinity levels when grown on agar as opposed to filter paper or hydroponic systems. Camberato and Martin (2004) suggested that evaporative water losses increase salinity on filter paper, which would
Salinity had no effect on final germination percentage for perennial ryegrass when grown on agar and did not vary significantly across salinities levels ranging from 0.6 to 12.5 $\mathrm{dS} \cdot \mathrm{m}^{-1}$ when germinated on filter paper. Final germination percentages exceeded $75 \%$ across all salinity levels and both media (Table 3 ). These results support the findings of Dudeck and Peacock (1985), Harivandi et al. (1982), and Horst and Dunning (1989) who all found that germination of perennial ryegrass was tolerant to salinity, even to levels found in sea water (Harivandi et al. 1982). Tall fescue exhibited a similar tolerance to salinity with final germination greater than $75 \%$ at all salinity levels and media. Our findings differ from those of Horst and Beadle (1984) and Zhang et al. (2011) who reported declining germination with increasing salinity in tall fescue. However, these authors used different methodologies to test salt tolerance: Zhang et al. (2011) used $\mathrm{NaCl}$ as the only source of salt and Horst and Beadle (1984) used floating mats in a saline solution. Hydroponic solutions and $\mathrm{NaCl}$ have both been shown to affect germination differently than other growth media (Zhang et al., 2011) or salts $\left(\mathrm{MgCl}_{2}\right.$ or $\mathrm{CaCl}_{2}$ ) (Lunt et al., 1961; Wu, 1981). Kentucky bluegrass and bermudagrass maintained high germination in agar across all salinities, but germination dropped below $75 \%$ on filter paper at the highest salinity level of $22.5 \mathrm{dS} \cdot \mathrm{m}^{-1}$, exhibiting values of $44 \%$ and $69 \%$, respectively (Table 3 ). Final germination percentage of seashore paspalum was low at all salinities tested, ranging from $\approx 60 \%$ at levels lower than $7.0 \mathrm{dS} \cdot \mathrm{m}^{-1}$ to $14 \%$ at $22.5 \mathrm{dS} \cdot \mathrm{m}^{-1}$ (Table 3 ). Our findings are similar to those of Johnson et al. (2007), who reported a germination percentage of $65 \%$ for 'Sea Spray' seashore paspalum at salinity levels of 2.0 and $3.0 \mathrm{dS} \cdot \mathrm{m}^{-1}$. Shahba et al. (2008) documented generally low germination under highly saline conditions for halophytes, which, according to Dodd and Donovan (1999), can be explained by the high sensitivity of halophytic grasses to osmotic stress during the germination stage. Carpenter (1958) attributed the generally low germination of seashore paspalum to selfincompatibility and the resulting high percentage of sterile seeds.

When data were pooled over germination media but analyzed separately for each grass, seed coating affected FGP negatively in only two of 25 treatment combinations (five grasses $\times$ five salinity levels). Coated seashore paspalum and perennial ryegrass seeds exhibited increased germination at four of the five salinity levels. Germination of coated tall fescue seeds was higher than for uncoated seeds at 0.6 and $12.5 \mathrm{dS} \cdot \mathrm{m}^{-1}$ (Table 3 ). Seed coating had no effect on FGP of bermudagrass at any salinity levels (Table 3 ). Kentucky bluegrass was the only grass tested that showed reduced germination from coated seed, but only at two of the five salinity levels $\left(0.6\right.$ and $\left.7.0 \mathrm{dS} \cdot \mathrm{m}^{-1}\right)$. Tall fescue and perennial ryegrass maintained FGP greater than $75 \%$ across all salinities and seed coatings as did bermudagrass and kentucky bluegrass at salinities between 0.6 
and $12.5 \mathrm{dS} \cdot \mathrm{m}^{-1}$. Final germination percentage for seashore paspalum improved greatly at the highest salinity levels when coated seed was used, increasing from $22 \%$ to $54 \%$ at $12.5 \mathrm{dS} \cdot \mathrm{m}^{-1}$ and from $8 \%$ to $20 \%$ at 22.5 $\mathrm{dS} \cdot \mathrm{m}^{-1}$ when coated seed was compared with uncoated (Table 3 ). When potable water was used, coating had a negative effect on germination of kentucky bluegrass and a positive effect on tall fescue (Table 3). These results differ from those reported by Richardson and Hignight (2010), who found that ZEBA ${ }^{\circledR}$ coating had no effect on seedling emergence of tall fescue in three soil types or on kentucky bluegrass emergence in two of three soil types. Contrary to Richardson and Hignight (2010), Leinauer et al. (2010) found increased field emergence of coated 'Bengal' creeping bentgrass and improved establishment of several cool-season blends and mixes when seed was coated. However, no other published reports are currently available on the effect of seed coating on the germination, emergence, or establishment of warm- and cool-season grasses.

Germination rate. All main effects except seed coating affected GR (Table 2). Germination rates for perennial ryegrass and

Table 4. Germination rates $(\% / \mathrm{d})$ of five turfgrass species. $^{z}$

\section{Grass}

\section{Bermudagrass}

Kentucky bluegrass

Perennial ryegrass

Seashore paspalum

Tall fescue

${ }^{\mathrm{z}}$ Data are pooled over five salinity levels, two germination media, two seed coatings, and four replications, and represent an average of 80 data points.

${ }^{y}$ Values followed by the same letter are not significantly different from one another (Fisher's protected least significant difference, $\alpha=0.05$ ).

Table 5. Germination rates (\%/d) of several turfgrasses at five salinity levels. ${ }^{2}$

\begin{tabular}{cc}
\hline Salinity $\left(\mathrm{dS} \cdot \mathrm{m}^{-1}\right)$ & \\
\hline 0.6 & $10 \mathrm{a}^{\mathrm{y}}$ \\
2.2 & $10 \mathrm{a}$ \\
7.0 & $9 \mathrm{a}$ \\
12.5 & $9 \mathrm{a}$ \\
22.5 & $7 \mathrm{~b}$ \\
\hline
\end{tabular}

${ }^{\mathrm{z}}$ Data are pooled over five turfgrasses, two media, two coatings, and four replications, and represent an average of 80 data points.

${ }^{y}$ Values followed by the same letter are not significantly different from one another (Fisher's protected least significant difference, $\alpha=0.05$ ).

Table 6. Germination rates $(\% / \mathrm{d})$ of several turfgrasses on two germination media. ${ }^{2}$

\begin{tabular}{l}
\hline Media \\
$\begin{array}{l}\text { Agar } \\
\text { Paper }\end{array}$ \\
$\begin{array}{l}{ }^{2} \text { Data are pooled over five turfgrasses, five salinity } \\
\text { levels, two coatings, and four replications, and }\end{array}$ \\
represent an average of 200 data points. \\
'Values followed by the same letter are not \\
significantly different from one another (Fisher's \\
protected least significant difference, $\alpha=0.05$ ).
\end{tabular}

bermudagrass were highest $(13 \%$ and $12 \% / \mathrm{d}$, respectively) followed by tall fescue and kentucky bluegrass $(9 \%$ and $7 \% / \mathrm{d}$, respectively). Seashore paspalum showed the slowest germination rate, averaging 4\%/d (Table 4). Our findings support those of Peacock and Dudeck (1989) who also found GR of 13\%/ $\mathrm{d}$ for bermudagrass at salinity levels as high as $9 \mathrm{dS} \cdot \mathrm{m}^{-1}$. When data were pooled overall grasses, media, and seed coatings, and listed separately for each salinity level (Table 5), salinity levels ranging from 0.6 to 12.5 $\mathrm{dS} \cdot \mathrm{m}^{-1}$ did not affect GRs. Only the highest salinity treatment of $22.5 \mathrm{dS} \cdot \mathrm{m}^{-1}$ reduced GR to an average of $7 \% / \mathrm{d}$ (Table 5). These results support those of Camberato and Martin (2004), who reported decreased GRs with increasing salinity for rough bluegrass. Our findings are also similar to those of Horst and Dunning (1989) who found that perennial ryegrass exhibited a $20 \%$ GR reduction at $23 \mathrm{dS} \cdot \mathrm{m}^{-1}$ when compared with tap water.

Generally, germination rates were higher on agar than on paper, averaging $10 \%$ and $8 \% / \mathrm{d}$, respectively (Table 6). This differs from results reported by Zhang et al. (2011) who found no differences in germination rates between media for several cool-season grasses. One possible reason could be that in contrast to our study, the authors used $\mathrm{NaCl}$ as the sole source of salinity. Several authors (Camberato and Martin, 2004; Dudeck et al., 1986; Zhang et al., 2011) have reported on the tendency of filter paper to lose water. In our study, we observed dew formation on the lids of the plastic containers; this water evaporation resulted in the filter paper drying out. The repeated rewatering of dry filter papers with saline water is required by the testing protocol (AOSA, 2009) and may have increased salinity levels over time. Agar plates did not require such a procedure. The potential increase in salinity caused by frequent rewatering of filter papers was also mentioned by Dudeck et al. (1986) and Zhang et al. (2011).

Our study suggests that the choice of medium can influence the outcome of germination tests and that results will also vary depending on the salinity level tested and whether the seed are coated. Filter paper is currently the medium recommended by the Association of Official Seed Analysts, but agar improved both FGP and GR for most turfgrasses in several of the salinity levels investigated. Germination of turfgrasses investigated in our study varied widely under salinities ranging from 0.6 to $22.5 \mathrm{dS} \cdot \mathrm{m}^{-1}$. Seashore paspalum, a species described by numerous researchers as a halophyte with superior salt tolerance, exhibited poorest germination under both potable and saline conditions. Despite the significant differences in germination between bermudagrass and seashore paspalum reported in this study, no corresponding differences in establishment have been observed between these two grasses when grown under saline irrigation (Schiavon, unpublished data). This suggests that germination tests alone may not be good predictors of salinity tolerances during establishment. The opposite also appears to be true in that plants such as seashore paspalum, which are well adapted to saline conditions once established, may be very sensitive to salinity at the germination stage. Furthermore, the question regarding which of the two media is more representative of field conditions remains unanswered. Additional studies are needed to compare laboratory germination to field emergence, establishment, and long-term performance under saline conditions. Only studies that include both germination and field trials will help to determine the usefulness of germination tests in providing relevant information on establishing and maintaining turf under saline conditions.

\section{Literature Cited}

Absorbent Technologies. 2006. Material safety data sheet ZEBA. 20 Apr. 2011. <http://www.zeba. com/pdfs/linked/20147_MSDS-All_Products. $\mathrm{pdf}>$.

AOSA. 2009. Rules for testing seeds. Association of Official Seed Analysts, Inc., Ithaca, NY.

Ardens, C. 2007. Innovations in turfgrass. TurfNews. 30:98-99.

Berdhal, J.D. and R.E. Barker. 1980. Germination and emergence of Russian wildrye seed coated with hydrophilic materials. Agron. J. 72:10061008.

Brilman, L.A. and F. Sardar. 2010. Salt tolerance in cool-season turfgrasses. 2nd Ed. ETS, Angers, France. p. 48-50.

Bruneau, A.H., C.H. Peacock, and J.M. Di Paola. 1989. Cool season turfgrass establishment with fertilizer coated seed. Intl. Turfgrass Soc. Res. J. 6:263-265.

Camberato, J.J. and S.B. Martin. 2004. Salinity slows germination of rough bluegrass. HortScience 39:394-397.

Carpenter, J.A. 1958. Production and use of seed in seashore paspalum. J. Inst. Agr. Sci. 24:252256.

Dai, J., D.R. Huff, and M.J. Schlossberg. 2009. Salinity effects on seed germination and vegetative growth of greens-type Poa annua relative to other cool-season turfgrass species. Crop Sci. 49:696-703.

Dewey, D.R. 1962. Germination of crested wheatgrass in salinized soil. Agron. J. 54:353-355.

Dodd, G.L. and L.A. Donovan. 1999. Water potential and ionic effect on germination and seedling growth of two cold desert shrubs. Amer. J. Bot. 86:1146-1153.

Dudeck, A.E. and C.H. Peacock. 1985. Salinity effects on perennial ryegrass germination. HortScience 20:268-269.

Dudeck, A.E., C.H. Peacock, and T.J. Sheehan. 1986. An evaluation of germination media for turfgrass salinity studies. J. Amer. Soc. Hort. Sci. 111:170-173.

Greipson, S. 1999. Seed coating improves establishment of surface seeded Poa pratensis used in revegetation. Seed Sci. Technol. 27:10291032.

Harivandi, M.A., J.D. Butler, and P.M. Soltanpour. 1982. Salt influence on germination and seedling survival of six cool season turfgrass species. Commun. Soil Sci. Plant Anal. 13:519-529.

Hathcock, A.L., P.H. Dernoeden, J.J. Murray, and D.J. Wehner. 1984a. Seed germination of tall fescue and kentucky bluegrass as affected by adhesives. HortScience 19:442-443.

Hathcock, A.L., P.H. Dernoeden, T.R. Turner, and M.S. McIntosh. 1984b. Tall fescue and kentucky bluegrass response to fertilizer and lime seed coating. Agron. J. 76:879-882. 
Horst, G.L. and N.B. Beadle. 1984. Salinity affects germination and growth of tall fescue cultivars. J. Amer. Soc. Hort. Sci. 109:419-422.

Horst, G.L. and N.B. Dunning. 1989. Germination and seedling growth of perennial ryegrass in soluble salt. J. Amer. Soc. Hort. Sci. 114:338342 .

Horst, G.L. and R.M. Taylor. 1983. Germination and initial growth of kentucky bluegrass in soluble salts. Agron. J. 75:679-681.

Hummel Jr., N.W. 1991. Coated seed. Ground Maintenance 26:20, 22, 26.

Johnson, C.J., B. Leinauer, A.L. Ulery, D.E. Karcher, R.M. Goss. 2007. Moderate salinity does not affect germination of several cool- and warm-season turfgrasses. Appl. Turf Sci. 1-7.

Kaufman, G. 1991. Seed coating: A tool for stand establishment-A stimulus to seed quality. HortTechnology 1:98-102.

Leinauer, B., M. Serena, and D. Singh. 2010. Seed coating and seeding rate effects on turfgrass germination and establishment. HortTechnology 20:179-185.

Lunt, O.R., V.B. Youngner, and J.J. Oertli. 1961. Salinity tolerance of five turfgrass varieties. Agron. J. 53:247-249.

Maguire, J.D. 1962. Speed of germination: Aid in selection and evaluation for seedling emergence and vigor. Crop Sci. 2:176-177.
Marcar, N.E. 1987. Salt tolerance in the genus Lolium (ryegrass) during germination and growth. Aust. J. Agr. Res. 38:297-307.

McCarty, L.B. and A.E. Dudeck. 1993. Salinity effects on bentgrass germination. HortScience 28:15-17.

Newell, A.J. 1997. Effect of different seed treatments and coatings on the germination and establishment of four grass species. J. Sports Turf Res. Inst. 73:67-72.

Newell, A.J., J.C. Hart-Woods, and F.M.E. Crossley. 1999. Investigation of the effects of fortiva seed treatment on the establishment of different grass species and mixtures. J. Sports Turf Res. Inst. 75:89-99.

Peacock, C.H. and A.E. Dudeck. 1989. Influence of salinity on warm season turfgrass germination. The 6th Int. Turf. Research Conf., Tokyo, Japan. p. 229-231.

Qian, Y.L. and M.R. Suplick. 2001. Interactive effects of salinity and temperature on kentucky bluegrass and tall fescue seed germination. Intl. Turf. Soc. 9:334-339.

Richardson, M.D. and K.W. Hignight. 2010. Seedling emergence of tall fescue and kentucky bluegrass, as affected by two seed coating techniques. HortTechnology 20:415-417.

Richardson, M.D. and J.H. McCalla. 2008. Germination of three ryegrass species and meadow fescue under saline conditions. Arkansas Agr. Exp. Stnd. Res. Ser. 557:63-65.

Ross, E.E. and F.D. Moore. 1975. Effect of seed coating on performance of lettuce seeds in greenhouse soil test. J. Amer. Soc. Hort. Sci. 100:573-576

Scott, J.M. 1989. Seed coatings and treatments and their effects on plant establishment. Adv. Agron. 42:43-83.

Serena, M., B. Leinauer, S. Macolino, and M. Gill. 2010. Germination of coated and uncoated turfgrass seed under saline conditions. 2nd Ed. ETS, Angers, France, 2010. p. 199-201.

Shahba, M.A., Y.L. Qian, and K.D. Lair. 2008. Improving seed germination of saltgrass under saline conditions. Crop Sci. 48:756-762.

Torello, W.A. and A.G. Symington. 1984. Screening of turfgrass species and cultivars for $\mathrm{NaCl}$ tolerance. Plant Soil 82:155-161.

Wang, S. and Q. Zhang. 2010. Responses of creeping bentgrass to salt stress during in vitro germination. HortScience 45:1747-1750.

$\mathrm{Wu}, \mathrm{L}$. 1981. The potential for evaluation of salinity tolerance in Agrostis stolonifera L. and Agrostis tenuis Sibth. New Phytol. 89:471486.

Zhang, Q., S. Wang, and K. Rue. 2011. Salinity tolerance of 12 turfgrasses in three germination media. HortScience 46:651-654. 